4

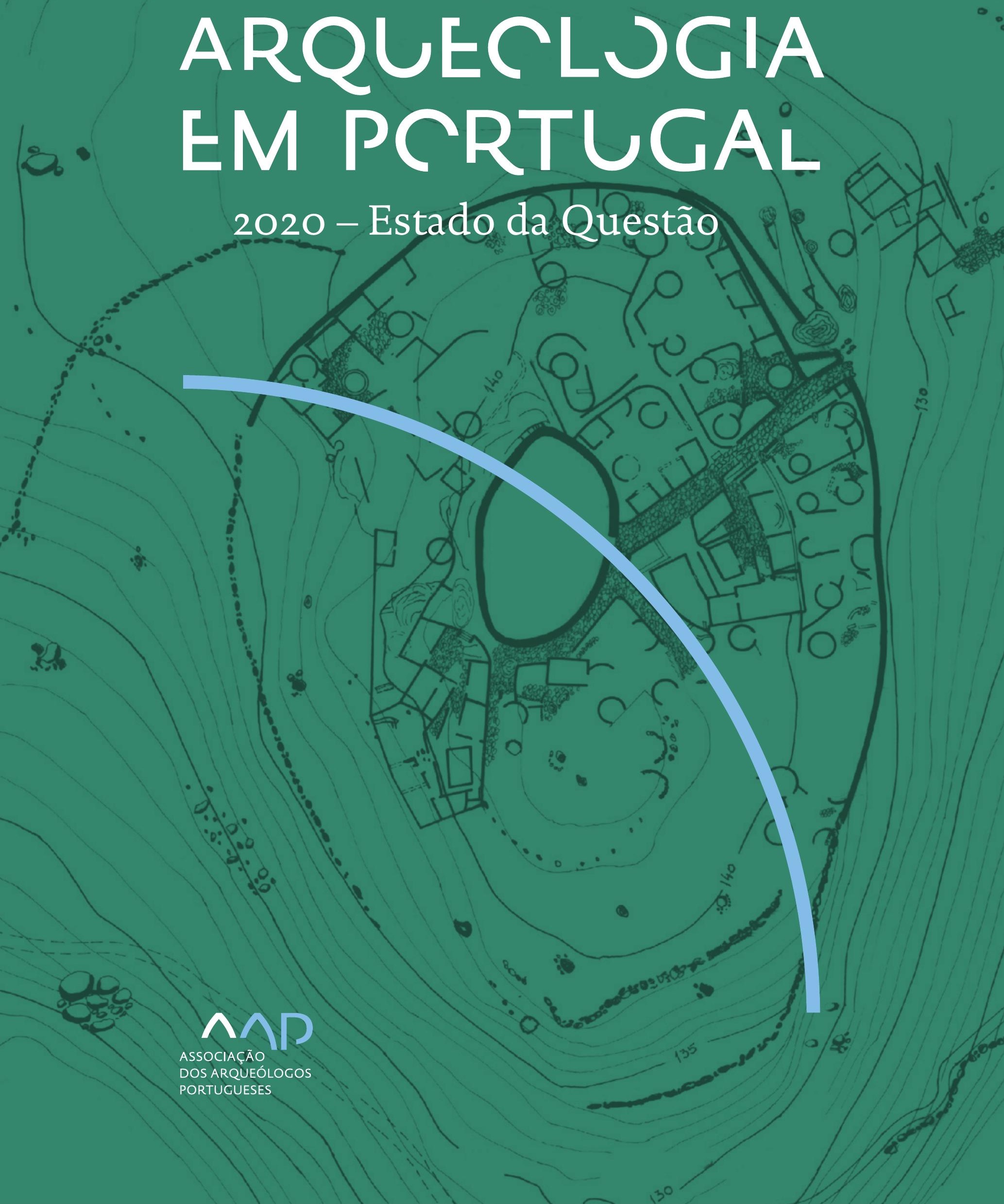


Coordenação editorial: José Morais Arnaud, César Neves e Andrea Martins Design gráfico: Flatland Design

AAP - ISBN: 978-972-9451-89-8

CITCEM - ISBN: 978-989-8970-25-1

Associação dos Arqueólogos Portugueses e CITCEM

Lisboa, 2020

O conteúdo dos artigos é da inteira responsabilidade dos autores. Sendo assim a Associação dos Arqueólogos Portugueses declina qualquer responsabilidade por eventuais equívocos ou questões de ordem ética e legal.

Desenho de capa:

Planta do castro de Monte Mozinho (Museu Municipal de Penafiel).

\section{$\hat{\wedge} \mathrm{P}$}

DOS ARQUEÓLOGOS PORTUGUESES

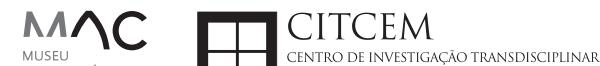
MUSEU
ARQUELLÓGICO
DO CARMO
U.PORTO

FLUP FACULDADE DE LETRAS
UNIVERSIDADE DO PORTO

Apoio

EC para a Ciência 


\section{Índice}

15 Prefácio

José Morais Arnaud

\section{Historiografia e Teoria}

17 Território, comunidade, memória e emoção: a contribuição da história da arqueologia (algumas primeiras e breves reflexões)

Ana Cristina Martins

25 Como descolonizar a arqueologia portuguesa?

Rui Gomes Coelho

41 Arqueologia e Modernidade: uma revisitação pessoal e breve de alguns aspetos da obra homónima de Julian Thomas de 2004

Vítor Oliveira Jorge

57 Dados para a História das Mulheres na Arqueologia portuguesa, dos finais do século XIX aos inícios do século XX: números, nomes e tabelas

Filipa Dimas / Mariana Diniz

73 Retractos da arqueologia portuguesa na imprensa: (in)visibilidades no feminino

Catarina Costeira / Elsa Luís

85 Arqueologia e Arqueólogos no Norte de Portugal Jacinta Bugalhão

101 Vieira Guimarães (1864-1939) e a arqueologia em Tomar: uma abordagem sobre o território e as gentes

João Amendoeira Peixoto / Ana Cristina Martins

115 Os memoráveis? A arqueologia algarvia na imprensa nacional e regional na presente centúria (2001-2019): características, visões do(s) passado(s) e a arqueologia

enquanto marca

Frederico Agosto / João Silva

129 A Evolução da Arqueologia Urbana e a Valorização Patrimonial no Barlavento Algarvio: Os casos de Portimão e Silves

Artur Mateus / Diogo Varandas / Rafael Boavida

\section{Gestão, Valorização e Salvaguarda do Património}

145 O Caderno Reivindicativo e as condições de trabalho em Arqueologia Miguel Rocha / Liliana Matias Carvalho / Regis Barbosa / Mauro Correia / Sara Simões / Jacinta Bugalhão / Sara Brito / Liliana Veríssimo Carvalho / Richard Peace / Pedro Peça / Cézer Santos

155 Os Estudos de Impacte Patrimonial como elemento para uma estratégia sustentável de minimização de impactes no âmbito de reconversões agrícolas Tiago do Pereiro

165 Salvaguarda de Património arqueológico em operações florestais: gestão e sensibilização Filipa Bragança / Gertrudes Zambujo / Sandra Lourenço / Belém Paiva / Carlos Banha / Frederico Tatá Regala / Helena Moura / Jacinta Bugalhão / João Marques / José Correia / Pedro Faria / Samuel Melro

179 Os valores do Património: uma investigação sobre os Sítios Pré-históricos de Arte Rupestre do Vale do Rio Côa e de Siega Verde José Paulo Francisco 
189 Conjugando recursos arqueológicos e naturais para potenciar as visitas ao Geoparque Litoral de Viana do Castelo (Noroeste de Portugal)

Hugo A. Sampaio / Ana M.S. Bettencourt / Susana Marinho / Ricardo Carvalhido

203 Áreas de Potencial Arqueológico na Região do Médio Tejo: Modelo Espacial Preditivo Rita Ferreira Anastácio / Ana Filipa Martins / Luiz Oosterbeek

223 Património Arqueológico e Gestão Territorial: O contributo da Arqueologia para a revisão do PDM de Avis

Ana Cristina Ribeiro

237 A coleção arqueológica do extinto Museu Municipal do Porto - Origens, Percursos e Estudos

Sónia Couto

251 Valpaços - uma nova carta arqueológica

Pedro Pereira / Maria de Fátima Casares Machado

263 Arqueologia na Cidade de Peniche

Adriano Constantino / Luís Rendeiro

273 Arqueologia Urbana: a cidade de Lagos como caso de Estudo Cátia Neto

285 Estratégias de promoção do património cultural subaquático nos Açores. O caso da ilha do Faial

José Luís Neto / José Bettencourt / Luís Borges / Pedro Parreira

297 Carta Arqueológica da Cidade Velha: Uma primeira abordagem

Jaylson Monteiro / Nireide Tavares / Sara da Veiga / Claudino Ramos / Edson Brito /

Carlos Carvalho / Francisco Moreira / Adalberto Tavares

311 Antropologia Virtual: novas metodologias para a análise morfológica e funcional Ricardo Miguel Godinho / Célia Gonçalves

\section{Didáctica da Arqueologia}

327 Como os projetos de Arqueologia podem contribuir para uma comunidade culturalmente mais consciente Alexandra Figueiredo / Claúdio Monteiro / Adolfo Silveira / Ricardo Lopes

337 Educação Patrimonial - Um cidadão esclarecido é um cidadão ativo! Ana Paula Almeida

351 A aproximação da Arqueologia à sala de aula: um caso de estudo no $3^{\circ}$ ciclo do Ensino Básico Luís Serrão Gil

363 Arqueologia 3.o - Pensar e comunicar a Arqueologia para um futuro sustentável Mónica Rolo

377 “Conversa de Arqueólogos" - Divulgar a Arqueologia em tempos de Pandemia Diogo Teixeira Dias

389 Escola Profissional de Arqueologia: desafios e oportunidades Susana Nunes / Dulcineia Pinto / Júlia Silva / Ana Mascarenhas

399 Os Museus de Arqueologia e os Jovens: a oferta educativa para o público adolescente Beatriz Correia Barata / Leonor Medeiros

411 O museu universitário como mediador entre a ciência e a sociedade: o exemplo da secção de arqueologia no Museu de História Natural e da Ciência da Universidade do Porto (MHNC-UP)

Rita Gaspar 
421 Museu de Lanifícios: Real Fábrica de Panos. Atividades no âmbito da Arqueologia Beatriz Correia Barata / Rita Salvado

427 Arqueologia Pública e o caso da localidade da Mata (Torres Novas) Cláudia Manso / Ana Rita Ferreira / Cristiana Ferreira / Vanessa Cardoso Antunes

431 Do sítio arqueológico ao museu: um percurso (também) didático Lídia Fernandes

447 Estão todos convidados para a Festa! E para dançar também... O projecto do Serviço Educativo do Museu Arqueológico do Carmo na $5^{\underline{a}}$ Edição da Festa da Arqueologia Rita Pires dos Santos

459 O “Clã de Carenque”, um projeto didático de arqueologia Eduardo Gonzalez Rocha

469 Mediação cultural: peixe que puxa carroça nas Ruínas Romanas de Troia Inês Vaz Pinto / Ana Patrícia Magalhães / Patrícia Brum / Filipa Santos

481 Didática Arqueológica, experiências do Projeto Mértola Vila Museu Maria de Fátima Palma / Clara Rodrigues / Susana Gómez / Lígia Rafael

\section{Arte Rupestre}

497 Os inventários de arte rupestre em Portugal Mila Simões de Abreu

513 O projeto FIRST-ART - conservação, documentação e gestão das primeiras manifestações de arte rupestre no Sudoeste da Península Ibérica: as grutas do Escoural e Maltravieso Sara Garcês / Hipólito Collado / José Julio García Arranz / Luiz Oosterbeek / António Carlos Silva / Pierluigi Rosina / Hugo Gomes / Anabela Borralheiro Pereira / George Nash / Esmeralda Gomes / Nelson Almeida / Carlos Carpetudo

523 Trabalhos de documentação de arte paleolítica realizados no âmbito do projeto PalæoCôa André Tomás Santos / António Fernando Barbosa / Luís Luís / Marcelo Silvestre / Thierry Aubry

537 Imagens fantasmagóricas, silhuetas elusivas: as figuras humanas na arte do Paleolítico Superior da região do Côa Mário Reis

$55^{1}$ Os motivos zoomórficos representados nas placas de tear de Vila Nova de São Pedro (Azambuja, Portugal) Andrea Martins / César Neves / José M. Arnaud / Mariana Diniz

571 Arte Rupestre do Monte de Góios (Lanhelas, Caminha). Síntese dos resultados dos trabalhos efectuados em 2007-2009 Mário Varela Gomes

599 Gravuras rupestres de barquiformes no Monte de S. Romão, Guimarães, Noroeste de Portugal Daniela Cardoso

613 Círculos segmentados gravados na Bacia do Rio Lima (Noroeste de Portugal): contributos para o seu estudo Diogo Marinho / Ana M.S. Bettencourt / Hugo Aluai Sampaio

631 Equídeos gravados no curso inferior do Rio Mouro, Monção (NW Portugal). Análise preliminar Coutinho, L.M. / Bettencourt, A.M.S / Sampaio, Hugo A.S

645 Paletas na Arte Rupestre do Noroeste de Portugal. Inventário preliminar Bruna Sousa Afonso / Ana M. S. Bettencourt / Hugo A. Sampaio 


\section{Pré-História}

661 O projeto Miño/Minho: balanço de quatro anos de trabalhos arqueológicos Sérgio Monteiro-Rodrigues / João Pedro Cunha-Ribeiro / Eduardo Méndez-Quintas / Carlos Ferreira / Pedro Xavier / José Meireles / Alberto Gomes / Manuel Santonja / Alfredo Pérez-González

677 A ocupação paleolítica da margem esquerda do Baixo Minho: a indústria lítica do sítio de Pedreiras 2 (Monção, Portugal) e a sua integração no contexto regional Carlos Ferreira / João Pedro Cunha-Ribeiro / Sérgio Monteiro-Rodrigues / Eduardo Méndez-Quintas / Pedro Xavier / José Meireles / Alberto Gomes / Manuel Santonja / Alfredo Pérez-González

693 O sítio acheulense do Plistocénico médio da Gruta da Aroeira Joan Daura / Montserrat Sanz / Filipa Rodrigues / Pedro Souto / João Zilhão

703 As sociedades neandertais no Barlavento algarvio: modelos preditivos com recurso aos SIG

Daniela Maio

715 A utilização de quartzo durante o Paleolítico Superior no território dos vales dos rios Vouga e Côa

Cristina Gameiro / Thierry Aubry / Bárbara Costa / Sérgio Gomes / Luís Luís / Carmen Manzano / André Tomás Santos

733 Uma perspetiva diacrónica da ocupação do concheiro do Cabeço da Amoreira (Muge, Portugal) a partir da tecnologia lítica Joana Belmiro / João Cascalheira / Célia Gonçalves

745 Novos dados sobre a Pré-história Antiga no concelho de Palmela. A intervenção arqueológica no sítio do Poceirão I

Michelle Teixeira Santos

757 Problemas em torno de Datas Absolutas Pré-Históricas no Norte do Alentejo Jorge de Oliveira

771 Povoamento pré-histórico nas áreas montanhosas do NO de Portugal: o Abrigo 1 de Vale de Cerdeira Pedro Xavier / José Meireles / Carlos Alves

783 Apreciação do povoamento do Neolítico Inicial na Baixa Bacia do Douro. A Lavra I (Serra da Aboboreira) como caso de estudo Maria de Jesus Sanches

797 O Processo de Neolitização na Plataforma do Mondego: os dados do Sector C do Outeiro dos Castelos de Beijós (Carregal do Sal)

João Carlos de Senna-Martinez / José Manuel Quintã Ventura / Andreia Carvalho / Cíntia Maurício

823 Novos trabalhos na Lapa da Bugalheira (Almonda, Torres Novas) Filipa Rodrigues / Pedro Souto / Artur Ferreira / Alexandre Varanda / Luís Gomes / Helena Gomes / João Zilhão

837 A pedra polida e afeiçoada do sítio do Neolítico médio da Moita do Ourives (Benavente, Portugal)

César Neves

857 Casal do Outeiro (Encarnação, Mafra): novos contributos para o conhecimento do povoamento do Neolítico final na Península de Lisboa.

Cátia Delicado / Carlos Maneira e Costa / Marta Miranda / Ana Catarina Sousa

873 Stresse infantil, morbilidade e mortalidade no sítio arqueológico do Neolítico Final/ Calcolítico ( $4^{\circ}$ e $3^{\circ}$ milénio a.C.) do Monte do Carrascal 2 (Ferreira do Alentejo, Beja) Liliana Matias de Carvalho / Sofia N. Wasterlain 
885 Come together: O Conjunto Megalítico das Motas (Monção, Viana do Castelo) e as expressões Campaniformes do Alto Minho Ana Catarina Basílio / Rui Ramos

899 Trabalhos arqueológicos no sítio Calcolítico da Pedreira do Poio Carla Magalhães / João Muralha / Mário Reis / António Batarda Fernandes

913 O sítio arqueológico de Castanheiro do Vento. Da arquitectura do sítio à arquitectura de um território João Muralha Cardoso

925 Estudo zooarqueológico das faunas do Calcolítico final de Vila Nova de São Pedro (Azambuja, Portugal): Campanhas de 2017 e 2018 Cleia Detry / Ana Catarina Francisco / Mariana Diniz / Andrea Martins / César Neves / José Morais Arnaud

943 As faunas depositadas no Museu Arqueológico do Carmo provenientes de Vila Nova de São Pedro (Azambuja): as campanhas de 1937 a 1967 Ana Catarina Francisco / Cleia Detry / César Neves / Andrea Martins / Mariana Diniz / José Morais Arnaud

959 Análise funcional de material lítico em sílex do castro de Vila Nova de S. Pedro (Azambuja, Portugal): uma primeira abordagem Rafael Lima

971 O recinto da Folha do Ouro 1 (Serpa) no contexto dos recintos de fossos calcolíticos alentejanos

António Carlos Valera / Tiago do Pereiro / Pedro Valério / António M. Monge Soares

\section{Proto-História}

987 Produção de sal marinho na Idade do Bronze do noroeste Português. Alguns dados para uma reflexão

Ana M. S. Bettencourt / Sara Luz / Nuno Oliveira / Pedro P. Simões / Maria Isabel C. Alves / Emílio Abad-Vidal

1001 A estátua-menir do Pedrão ou de São Bartolomeu do Mar (Esposende, noroeste de Portugal) no contexto arqueológico da fachada costeira de entre os rios Neiva e Cávado Ana M. S. Bettencourt / Manuel Santos-Estévez / Pedro Pimenta Simões / Luís Gonçalves

1015 O Castro do Muro (Vandoma/Baltar, Paredes) - notas para uma biografia de ocupação da Idade do Bronze à Idade Média

Maria Antónia D. Silva / Ana M. S. Bettencourt / António Manuel S. P. Silva / Natália Félix

1031 Do Bronze Final à Idade Média - continuidades e hiatos na ocupação de Povoados em Oliveira de Azeméis João Tiago Tavares / Adriaan de Man

1041 As faunas do final da Idade do Bronze no Sul de Portugal: leituras desde o Outeiro do Circo (Beja)

Nelson J. Almeida / Íris Dias / Cleia Detry / Eduardo Porfírio / Miguel Serra

1055 A Espada do Monte das Oliveiras (Serpa) - uma arma do Bronze Pleno do Sudoeste Rui M. G. Monge Soares / Pedro Valério / Mariana Nabais / António M. Monge Soares

1065 São Julião da Branca (Albergaria-a-Velha) - Investigação e valorização de um povoado do Bronze Final

António Manuel S. P. Silva / Paulo A. P. Lemos / Sara Almeida e Silva / Edite Martins de Sá

1083 Do castro de S. João ao Mosteiro de Santa Clara: notícia de uma intervenção arqueológica, em Vila do Conde Rui Pinheiro 
1095 O castro de Ovil (Espinho), um quarto de século de investigação - resultados e questões em aberto

Jorge Fernando Salvador / António Manuel S. P. Silva

1111 O Castro de Salreu (Estarreja), um povoado proto-histórico no litoral do Entre Douro e Vouga

Sara Almeida e Silva / António Manuel S. P. Silva / Paulo A. P. Lemos / Edite Martins de Sá

1127 Castro de Nossa Senhora das Necessidades (Sernancelhe): uma primeira análise artefactual Telma Susana O. Ribeiro

${ }_{1141}$ A cividade de Bagunte. O estado atual da investigação Pedro Brochado de Almeida

1153 Zoomorfos na cerâmica da Idade do Ferro no NW Peninsular: inventário, cronologias e significado Nuno Oliveira / Cristina Seoane

1163 Vasos gregos em Portugal: diferentes maneiras de contar a história do intercâmbio cultural na Idade do Ferro

Daniela Ferreira

1175 Os exotica da necrópole da Idade do Ferro do Olival do Senhor dos Mártires (Alcácer do Sal) no seu contexto regional

Francisco B. Gomes

\section{Antiguidade Clássica e Tardia}

1191 O uso de madeira como combustível no sítio da Quinta de Crestelos (Baixo Sabor): da Idade do Ferro à Romanização Filipe Vaz / João Tereso / Sérgio Simões Pereira / José Sastre / Javier Larrazabal Galarza / Susana Cosme / José António Pereira / Israel Espi

1207 Cultivos de Época Romana no Baixo Sabor: continuidade em tempos de mudança? João Pedro Tereso / Sérgio Simões Pereira / Filipe Santos / Luís Seabra / Filipe Vaz

1221 A casa romana na Hispânia: aplicação dos modelos itálicos nas províncias ibéricas Fernanda Magalhães / Diego Machado / Manuela Martins

1235 As pinturas murais romanas da Rua General Sousa Machado, n. ${ }^{5}$ 1, Chaves José Carvalho

1243 Trás do Castelo (Vale de Mir, Pegarinhos, Alijó) - Uma exploração agrícola romana do Douro

Tony Silvino / Pedro Pereira

1255 A sequência de ocupação no quadrante sudeste de Bracara Augusta: as transformações de uma unidade doméstica Lara Fernandes / Manuela Martins

1263 Os Mosaicos com decoração geométrica e geométrico-vegetalista dos sítios arqueológicos da área do Conuentus Bracaraugustanus. Novas abordagens quanto à conservação, restauro, decoração e datação Maria de Fátima Abraços / Licínia Wrench

1277 “Casa Romana” do Castro de São Domingos (Cristelos, Lousada): Escavação, Estudo e Musealização Paulo André de P. Lemos

1291 A arqueobotânica no Castro de Guifões (Matosinhos, Noroeste de Portugal): O primeiro estudo carpológico

Luís Seabra / Andreia Arezes / Catarina Magalhães / José Varela / João Pedro Tereso 
1305 Um Horreum Augustano na Foz do Douro (Monte do Castelo de Gaia, Vila Nova de Gaia) Rui Ramos

1311 Ponderais romanos na Lusitânia: padrões, formas, materiais e contextos de utilização Diego Barrios Rodríguez

1323 Um almofariz centro-itálico na foz do Mondego

Marco Penajoia

1335 Estruturas romanas de Carnide - Lisboa Luísa Batalha / Mário Monteiro / Guilherme Cardoso

1347 O contexto funerário do sector da "necrópole NO" da Rua das Portas de S. Antão (Lisboa): o espaço, os artefactos, os indivíduos e a sua interconectividade na interpretação do passado Sílvia Loja, José Carlos Quaresma, Nelson Cabaço, Marina Lourenço, Sílvia Casimiro, Rodrigo Banha da Silva, Francisca Alves-Cardoso

${ }_{1361}$ Povoamento em época Romana na Amadora - resultados de um projeto pluridisciplinar Gisela Encarnação / Vanessa Dias

1371 A Arquitectura Residencial em Mirobriga (Santiago do Cacém): contributo a partir de um estudo de caso Filipe Sousa / Catarina Felício

${ }_{1385}$ O fim do ciclo. Saneamento e gestão de resíduos nos edifícios termais de Mirobriga (Santiago do Cacém)

Catarina Felício / Filipe Sousa

1399 Balsa, Topografia e Urbanismo de uma Cidade Portuária Vítor Silva Dias / João Pedro Bernardes / Celso Candeias / Cristina Tété Garcia

1413 No Largo das Mouras Velhas em Faro (2017): novas evidências da necrópole norte de Ossonoba e da sua ocupação medieval Ricardo Costeira da Silva / Paulo Botelho / Fernando Santos / Liliana Nunes

1429 Instrumentos de pesca recuperados numa fábrica de salga em Ossonoba (Faro) Inês Rasteiro / Ricardo Costeira da Silva / Paulo Botelho

1439 A Necrópole Romana do Eirô, Duas Igrejas (Penafiel): intervenção arqueológica de 2016 Laura Sousa / Teresa Soeiro

1457 Ritual, descarte ou afetividade? A presença de Canis lupus familiaris na Necrópole Noroeste de Olisipo (Lisboa)

Beatriz Calapez Santos / Sofia Simões Pereira / Rodrigo Banha da Silva / Sílvia Casimiro / Cleia Detry / Francisca Alves Cardoso

1467 Dinâmicas económicas em Bracara na Antiguidade Tardia Diego Machado / Manuela Martins / Fernanda Magalhães / Natália Botica

1479 Cerâmicas e Vidros da Antiguidade Tardia do Edifício sob a Igreja do Bom Jesus (Vila Nova de Gaia) Joaquim Filipe Ramos

1493 Novos contributos para a topografia histórica de Mértola no período romano e na Antiguidade Tardia Virgílio Lopes

\section{8. Época Medieval}

1511 Cerâmicas islâmicas no Garb setentrional "português": algumas evidências e incógnitas Constança dos Santos / Helena Catarino / Susana Gómez / Maria José Gonçalves / Isabel Inácio / Gonçalo Lopes / Jacinta Bugalhão / Sandra Cavaco / Jaquelina Covaneiro / Isabel Cristina Fernandes / Ana Sofia Gomes 
1525 Contributo para o conhecimento da cosmética islâmica, em Silves, durante a Idade Média Rosa Varela Gomes

1537 Yábura e o seu território - uma análise histórico-arqueológica de Évora entre os séculos VIII-XII José Rui Santos

1547 A encosta sul do Castelo de Palmela - resultados preliminares da escavação arqueológica Luís Filipe Pereira / Michelle Teixeira Santos

1559 A igreja de São Lourenço (Mouraria, Lisboa): um conjunto de silos e de cerâmica medieval islâmica

Andreia Filipa Moreira Rodrigues

1571 O registo material de movimentações populacionais no Médio Tejo, durante os séculos XII-XIII. Dois casos de "sunken featured buildings", nos concelhos de Cartaxo e Torres Novas Marco Liberato / Helena Santos / Nuno Santos

1585 O nordeste transmontano nos alvores da Idade média. Notas para reflexão Ana Maria da Costa Oliveira

1601 Sepulturas escavadas na rocha do Norte de Portugal e do Vale do Douro: primeiros resultados do Projecto SER-NPVD

Mário Jorge Barroca / César Guedes / Andreia Arezes / Ana Maria Oliveira

1619 "Portucalem Castrum Novum" entre o Mediterrâneo e o Atlântico: o estudo dos materiais cerâmicos alto-medievais do arqueossítio da rua de D. Hugo, nํ. 5 (Porto) João Luís Veloso

1627 A Alta Idade Média na fronteira de Lafões: notas preliminares sobre a Arqueologia no Concelho de Vouzela

Manuel Luís Real / Catarina Tente

1641 Um conjunto cerâmico medieval fora de portas: um breve testemunho aveirense Susana Temudo

${ }_{1651}$ Os Lóios do Porto: uma perspetiva integrada no panorama funerário da Baixa Idade Média à Época Moderna em meios urbanos em Portugal

Ana Lema Seabra

1659 O Caminho Português Interior de Santiago como eixo viário na Idade Média Pedro Azevedo

1665 Morfologia Urbana: Um exercício em torno do Castelo de Ourém André Donas-Botto / Jaqueline Pereira

1677 Intervenção arqueológica na Rua Marquês de Pombal/Largo do Espírito Santo (Bucelas, Loures)

Florbela Estêvão / Nathalie Antunes-Ferreira / Dário Ramos Neves / Inês Lisboa

1691 O Cemitério Medieval do Poço do Borratém e a espacialidade funerária na cidade de Lisboa Inês Belém / Vanessa Filipe / Vasco Noronha Vieira / Sónia Ferro / Rodrigo Banha da Silva

1705 Um Espaço Funerário Conventual do séc. XV em Lisboa: o caso do Convento de São Domingos da Cidade Sérgio Pedroso / Sílvia Casimiro / Rodrigo Banha da Silva / Francisca Alves Cardoso

\section{9. Época Moderna e Contemporânea}

1721 Arqueologia Moderna em Portugal: algumas reflexões críticas em torno da quantificação de conjuntos cerâmicos e suas inferências históricas e antropológicas Rodrigo Banha da Silva / André Bargão / Sara da Cruz Ferreira

1733 Faianças de dois contextos entre os finais do século XVI e XVIII do Palácio dos Condes de Penafiel, Lisboa

Martim Lopes / Tomás Mesquita 
1747 Um perfil de consumo do século XVIII na foz do Tejo: O caso do Mercado da Ribeira, Lisboa Sara da Cruz Ferreira / Rodrigo Banha da Silva / André Bargão

1761 Os Cachimbos dos Séculos XVII e XVIII do Palácio Mesquitela e Convento dos Inglesinhos (Lisboa)

Inês Simão / Marina Pinto / João Pimenta / Sara da Cruz Ferreira / André Bargão / Rodrigo Banha da Silva

1775 "Tomar os fumos da erua que chamão em Portugal erua sancta». Estudo de Cachimbos provenientes da Rua do Terreiro do Trigo, Lisboa

Miguel Martins de Sousa / José Pedro Henriques / Vanessa Galiza Filipe

1787 Cachimbos de Barro Caulínitico da Sé da Cidade Velha (República de Cabo Verde)

Rodrigo Banha da Silva / João Pimenta / Clementino Amaro

1801 Algumas considerações sobre espólio não cerâmico recuperado no Largo de Jesus (Lisboa) Carlos Boavida

1815 Adereços de vidro, dos séculos XVI-XVIII, procedentes do antigo Convento de Santana de Lisboa (anéis, braceletes e contas)

Joana Gonçalves / Rosa Varela Gomes / Mário Varela Gomes

1837 Da ostentação, luxo e poder à simplicidade do uso quotidiano: arqueologia e simbologia de joias e adornos da Idade Moderna Portuguesa Jéssica Iglésias

1849 Os amuletos em Portugal - dos objetos às superstições: o coral vermelho Alexandra Vieira

1865 Cerâmicas de Vila Franca de Xira nos séculos XV e XVI Eva Pires

1879 «Não passa por teu o que me pertence». Marcas de individualização associadas a faianças do Convento de Nossa Senhora de Aracoeli, Alcácer do Sal Catarina Parreira / Íris Fragoso / Miguel Martins de Sousa

1891 Cerâmica de Leiria: alguns focos de produção

Jaqueline Pereira / André Donas-Botto

1901 Os Fornos na Rua da Biquinha, em Óbidos Hugo Silva / Filipe Oliveira

1909 A casa de Pêro Fernandes, contador dos contos de D. Manuel I: o sítio arqueológico da Silha do Alferes, Seixal (século XVI) Mariana Nunes Ferreira

1921 O Alto da Vigia (Sintra) e a vigilância e defesa da costa Alexandre Gonçalves / Sandra Santos

1937 O contexto da torre sineira da Igreja de Santa Maria de Loures Paulo Calaveira / Martim Lopes

1949 A Necrópole do Hospital Militar do Castelo de São Jorge e as práticas funerárias na Lisboa de Época Moderna Susana Henriques / Liliana Matias de Carvalho / Ana Amarante / Sofia N. Wasterlain

1963 SAND - Sarilhos Grandes Entre dois Mundos: o adro da Igreja e a Paleobiologia dos ossos humanos recuperados

Paula Alves Pereira / Roger Lee Jesus / Bruno M. Magalhães

1975 Expansão urbana da vila de Cascais no século XVII e XVIII: a intervenção arqueológica na Rua da Vitória no 15 a 17

Tiago Pereira / Vanessa Filipe

1987 Novos dados para o conhecimento do Urbanismo de Faro em época Moderna Ana Rosa 
1995 Um exemplo de Arqueologia Urbana em Alcoutim: o Antigo Edifício dos CTT Marco Fernandes / Marta Dias / Alexandra Gradim / Virgílio Lopes / Susana Gómez Martínez

2007 Palácio dos Ferrazes (Rua das Flores/Rua da Vitória, Porto): a cocheira de Domingos Oliveira Maia

Francisco Raimundo

2021 As muitas vidas de um edifício urbano: História, Arqueologia e Antropologia no antigo Recreatório Paroquial de Penafiel Helena Bernardo / Jorge Sampaio / Marta Borges

2035 O convento de Nossa Senhora da Esperança de Ponta Delgada: o contributo da arqueologia para o conhecimento de um monumento identitário João Gonçalves Araújo / N’Zinga Oliveira

2047 Arqueologia na ilha do Corvo... em busca da capela de Nossa Senhora do Rosário Tânia Manuel Casimiro / José Luís Neto / Luís Borges / Pedro Parreira

2059 Perdidos à vista da Costa. Trabalhos arqueológicos subaquáticos na Barra do Tejo Jorge Freire / José Bettencourt / Augusto Salgado

2071 Arqueologia marítima em Cabo Verde: enquadramento e primeiros resultados do projecto CONCHA

José Bettencourt / Adilson Dias / Carlos Lima / Christelle Chouzenoux / Cristóvão Fonseca / Dúnia Pereira / Gonçalo Lopes / Inês Coelho / Jaylson Monteiro / José Lima / Maria Eugénia Alves / Patrícia Carvalho / Tiago Silva

2085 Trabalhos arqueológicos na Cidade Velha (Ribeira Grande de Santiago, Cabo Verde): reflexões sobre um projecto de investigação e divulgação patrimonial André Teixeira / Jaylson Monteiro / Mariana Mateus / Nireide Tavares / Cristovão Fonseca / Gonçalo C. Lopes / Joana Bento Torres / Dúnia Pereira / André Bargão / Aurélie Mayer / Bruno Zélie / Carlos Lima / Christelle Chouzenoux / Inês Henriques / Inês Pinto Coelho / José Lima / Patrícia Carvalho / Tiago Silva

2103 A antiga fortificação de Quelba / Khor Kalba (E.A.U.). Resultados de quatro campanhas de escavações, problemáticas e perspectivas futuras Rui Carita / Rosa Varela Gomes / Mário Varela Gomes / Kamyar Kamyad

2123 Colónias para homens novos: arqueologia da colonização agrária fascista no noroeste ibérico Xurxo Ayán Vila / José Mạ . Señorán Martín 


\title{
A CIVIDADE DE BAGUNTE. O ESTADO ATUAL DA INVESTIGAÇÃO
}

\author{
Pedro Brochado de Almeida ${ }^{1}$
}

\begin{abstract}
RESUMO
A Cividade de Bagunte é a mais divulgada estação arqueológica do concelho de Vila do Conde. Localizada num monte com ótima visibilidade para os territórios situados a norte e a sul do rio Ave, mereceu, já na ponta final do século XIX, o interesse de arqueólogos como Ricardo Severo e Martins Sarmento e na década de 40 da centúria seguinte de F. Russel Cortez. Sobretudo este realizou, ali, algumas campanhas de escavações que puseram a descoberto um misto de construções castrejas e romanas, distribuídas por espaços ortogonais que têm já a chancela da influência romana na região. Os trabalhos arqueológicos mais recentes permitem uma maior precisão quanto à sua evolução, embora subsistam muitas interrogações por decifrar.

Palavras-chave: Cividade, Cultura Castreja, Romanização.
\end{abstract}

\begin{abstract}
The Cividade of Bagunte is the most publicized archaeological site of the municipality of Vila do Conde. Located on a mound with great visibility over the territories to the north and south of the Ave River it called the attention and interest of various archaeologists such as Ricardo Severo and Martins Sarmento, in the end of the $19^{\text {th }}$ century, and F. Russell Cortez in the 40's of the next century. F. Russell Cortez organized digging campaigns at the site that uncovered a mixture Castrejo and Roman type buildings and structures, distributed by orthogonal spaces that already have the seal of a Roman influence in the region. The most recent archeological campaigns give us a higher precision to determine its evolution as a settlement, despite the many questions that remain unanswered.
\end{abstract}

Keywords: Cividade, Castrejo Culture, Roman period.

A Cividade de Bagunte localiza-se na freguesia com o mesmo nome, no concelho de Vila do Conde, num monte localmente conhecido por Cividade, Subidade, ou dos Sobreirinhos. Encontra-se classificada como Monumento Nacional desde 1910 (Decreto de 16-o6-1910, DG, n.. 136, de 23-o6-1910), sendo que atualmente a sua área classificada encontra-se em processo de ampliação (Anúncio n. $.^{\circ} 16 / 2016$, DR, 2..$^{\text {a }}$ série, $\mathrm{n} .{ }^{\circ} 12$, de 19-01-2016).

Trata-se de um povoado castrejo fortificado, central e romanizado que, tradicionalmente, tem sido enquadrado cronologicamente entre os séculos IV a.C. e IV d.C. (PINTO, 1997, 29; PINTO, 2003, 129), embora um estudo recente do espólio, depositado no Museu de História Natural e da Ciência da Universidade do Porto (a esta data ainda no prelo), permita afinar esta cronologia, como se verá mais adiante. Adicionalmente, escavações realizadas em conjunto pelo Gabinete de Arqueologia Municipal e pela University of Texas at Austin, determinou a existência de materiais cerâmicos e estruturas mais recentes, nomeadamente da Alta Idade Média.

Encontra-se implantado numa elevação com 206m de altura, num espaço geográfico que está delimitado pelo rio Este a norte, pelo rio Ave a sul e a oeste, embora um pouco mais distante, pelo oceano atlântico. O monte tem uma dimensão que se aproxima dos 5 oha, embora a zona arqueológica tenha uma área estimada seja inferior a essa cifra.

Em termos geológicos, a Cividade de Bagunte assenta sobre uma formação granítica que, a curta distância, faz fronteira com formações do complexo xisto-grauváquico, que se desenvolvem, no sentido noroeste-sudeste, desde a zona costeira de Esposende/Póvoa de Varzim até à região de Valongo/ Castelo de Paiva (TEIXEIRA, 1965).

1. Câmara Municipal de Vila do Conde - pedro.brochado@cm-viladoconde.pt 
Nas suas encostas nascem alguns fios de água que drenam para as bacias hidrográficas dos rios Este e Ave. Muitas destas linhas de água, de pequena relevância, mas importantes para um povoado fortificado da Idade Ferro Romanizado, foram artificialmente alteradas ao longos dos tempos mais recentes, nomeadamente pela construção de minas de água, das quais ainda se identificam alguns poços de ventilação/visita espalhados por todo o monte. Estas serviram, até há bem pouco tempo, para o regadio das extensas áreas agrícolas que se desenvolvem em seu redor, especialmente a este e a sul.

O monte apresenta uma configuração sub-arredondada,que assume um forte pendor nas vertentes voltadas a sul e oeste e uma inclinação suave na vertente norte e este. A noroeste e a sudeste existem dois esporões que, embora pouco evidentes, foram incluídos na área fortificada do povoado.

Um recente levantamento da biodiversidade ${ }^{2}$ constatou que, ao nível do coberto vegetal, o monte está densamente colonizado pelo eucaliptal, embora ainda subsistam algumas manchas de carvalhos, castanheiros e sobreiros. Com uma expressão maior encontram-se também os azevinhos, os sanguinhos-de-água e os salgueiros pretos. A presença destas duas espécies arbóreas é particularmente interessante por serem próprias de zonas húmidas. No que diz respeito às espécies arbustivas destaca-se a presença de várias espécies de ericas, de ulex, estevas, fetos, entre outras. Desde que, em 2015, o Município de Vila do Conde adquiriu 18ha da Cividade de Bagunte, tem sido possível regenerar as manchas de espécies autóctones, tendo com objetivo diminuir a presença do eucaliptal e controlar a outras espécies invasoras, nomeadamente de acácias.

A posição geográfica da Cividade de Bagunte permite-lhe ter um contacto visual com outros grandes povoados, como o Castro de Alvarelhos, a sul, ou a Cividade de Terroso, a norte. A sua posição também permite um controlo visual eficaz sobre um conjunto de povoados de menor dimensão que se erguiam nas suas imediações, nomeadamente o Castro Boi (Vairão), os castros de Casais e de Argifonso (situados em Arcos), de Retorta (Retorta), de S. Paio (Labruge), de Ferreiró (Ferreiró), de S. João (Vila do Conde).

Diversos autores identificaram-na como uma "povoação antiga”, pelo menos, desde o século XVIII,

2. Este levantamento foi realizado por técnicos do CMIA de Vila do Conde para a Câmara Municipal. quando foi mencionada por Jerónimo Contador de Argote, pelo Padre Carvalho da Costa, ou pelas Memórias Paroquiais, citadas por diversos estudiosos (PINTO, 2003, 126-127; ARGOTE, 1744; COSTA, 1868-1869).

A tentativa de a enquadrar cronologicamente começou, somente, no século XIX, quando entra na esfera de interesse de investigadores como Martins Sarmento (SARMENTO, 1999, 263-265; PINTO, 2003, 128). No entanto, foram Ricardo Severo e Fonseca Cardoso os primeiros a escavar na Cividade de Bagunte, em 1885 (SEVERO, 1886), tendo sido secundados por Mendes Correia, em 1915 (Arquivo da DGEMN - Cividade de Bagunte; ALMEIDA, 2015, 52). A intervenção arqueológica dirigida por Ricardo Severo e Artur Cardoso terá sido, inclusivamente, a responsável pela classificação da Cividade de Bagunte como Monumento Nacional, em 1910 (PINTO, 2003, 128).

A falta de um registo minucioso daquelas primeiras campanhas de escavação torna impossível localizar as áreas intervencionadas. Esta tarefa torna-se ainda mais difícil porque, na década de 40 do século XX, Fernando Russel Cortez empreendeu a maior campanha de escavação na Cividade de Bagunte (Arquivo da DGEMN - Cividade de Bagunte; ALMEIDA, 2015, 52-54).

É provável que os trabalhos da década de 40 do século XX tenham absorvido as zonas escavadas anteriormente. Todavia, a falta de uma publicação, ou registos detalhados dos trabalhos realizados por Russel Cortez torna impossível determinar quais as áreas escavadas por cada um dos investigadores (PINTO, 2003, 128-129). Tudo quanto Russel Cortez publicou sobre a Cividade de Bagunte reduz-se a um artigo datado de 1948 (CORTEZ, 1948, 269-281).

Estes trabalhos arqueológicos deixaram a descoberto parte do sistema defensivo, um misto de construções castrejas e romanas, distribuídas por espaços ortogonais, que já têm a chancela da influência romana na região. No total foi escavada uma área com $160 \mathrm{~m}$ de extensão (no sentido norte-sul) por cerca de $65 \mathrm{~m}$ de largura (no sentido este-oeste).

Seguiu-se um enorme desinteresse. No século XX nunca mais se escavou na Cividade de Bagunte. Este afastamento só foi sendo amenizado pela sua menção em alguns estudos científicos publicados durante os anos 8o e 9o do século passado (PINTO, 2003, 130-131; ALMEIDA, 1974; ROMERO MASIÁ, 1976; KALB, 1980; SILVA, 1986; CALO LOURIDO, 1994; 
QUEIROGA, 1996; DINIS, 1993; ALMEIDA, 1995; PINTO, 1998).

Esta tendência só foi quebrada com a criação do Gabinete de Arqueologia Municipal de Vila do Conde. Desde então foram realizados diversos esforços para resgatar as suas ruínas da floresta que, entretanto, cresceu em toda a área escavada. Foi também criado um primeiro documento que tinha por objetivo criar as bases do Parque Arqueológico da Cividade de Bagunte (PINTO, 2003, 125-159).

Adicionalmente foram feitos esforços para adquirir a sua propriedade, algo que se concretizou em 2015 e que incluiu toda a área com ruínas arqueológicas a descoberto.

Pouco antes foi possível, com o apoio de uma field-school anual da University of Texas at Austin, retomar as escavações arqueológicas, programa que dura até ao presente. Atualmente, o Gabinete de Arqueologia Municipal executa trabalhos arqueológicos, desde a escavação a trabalhos de conservação e manutenção anuais, com recursos a recursos humanos internos, mas também a o auxílio de alunos da Faculdade de Letras da Universidade do Porto.

As intervenções arqueológicas do século XXI concentraram-se na zona da acrópole da Cividade de Bagunte, área que foi divida em 8 Zonas artificiais que, por sua vez, foram divididos em quadrados.

Os trabalhos centram-se em quatro dessas zonas: 1 , 5,7 e 8 .

A grande maioria da área sondada foi dispersa por zonas que já haviam sido, de alguma forma, intervencionadas pelas campanhas do século XIX e XX (zonas 5,7 e 8). Os desafios desta decisão foram tomados de forma consciente, sabendo, à partida, que o registo estratigráfico poderia estar incompleto e perturbado. Contudo, também foi intervencionada uma área (zona 1), no âmbito da colaboração com a University of Texas at Austin, onde as garantias de preservação do registo estratigráfico eram superiores, por estar na periferia das intervenções arqueológicas mais antigas.

Tal como anteriormente referido, as propostas de datação para a Cividade de Bagunte enquadram a sua ocupação entre os séculos IV a.C. e IV d.C. (PINTO, 1997, 29; PINTO, 2003, 129), mas não tendo por base as escavações arqueológicas.

Um estudo recente, sobre os materiais da Cividade de Bagunte existentes no Museu de História Natural e da Ciência da Universidade do Porto, permite melhorar a sua cronologia, apontando para a exis- tência de materiais genericamente enquadráveis entre o período La Tène e o fim do Império (ALMEIDA, 2020) ${ }^{3}$.

Todavia, os resultados das escavações fornecem uma realidade diferente.

Contrariamente ao que acontece na Zona 1, onde o registo estratigráfico parece avançar até ao período Tardo-Romano, ou à Alta Idade Média, nas Zonas 5 , 7 e 8 o registo estratigráfico fica-se por uma cronologia que ronda o período dos Flávios (século I d.C.). Não avança para além desse período, mas também não recua. Se a escavação de Russel Cortez poderá explicar a falta de elementos arquitetónicos mais recentes, o mesmo não é viável para explicar a ausência dos mais antigos.

De acordo com os dados estratigráficos recolhidos nas campanhas arqueológicas realizadas recentemente, na Zona 1 aparecem estruturas Tardo-Romanas ou Alti-medievais. Estas caracterizam-se por muros onde a pedra é entremeada por tégula, disposta de forma pouco cuidada e onde se verifica a falta de alicerces assentes em terreno geológico. Nalgumas zonas preservaram lajeados que, à semelhança dos muros, denotam falta de empenho na construção de uma superfície regular. A forma como o edifício foi erguido denota uma clara falta de investimento, transmitindo a ideia de ser um refúgio transitório de alguém que recorreu à Cividade de Bagunte como local de habitação temporário, em tempos de incertezas.

Dado que as estruturas tardias encontradas na Zona 1 assentam sobre camadas de destruição das estruturas flavianas, parece ser seguro dizer-se que este movimento construtivo tardio corresponde a uma expansão/reocupação da Cividade de Bagunte. No entanto, os dados disponíveis não permitem, com segurança, afiançar se a Cividade de Bagunte, aquando daquela reocupação, estava totalmente abandonada, ou se este movimento correspondeu a uma nova fase de expansão.

É sabido que a instabilidade ganhou contornos conturbados na região aquando das invasões de Alanos, Suevos e Visigodos, sendo que muitas das populações locais hispano-romanas viram na orografia e nas muralhas dos castros uma forma eficaz de se manterem em segurança. Também são conhecidas as teses que defendem que muitos castros fo-

3. À data da redação deste artigo, o estudo ainda se encontrava no prelo. 
ram completamente abandonados, em detrimento do povoamento assente em núcleos urbanos e em villas, fomentado pelas políticas dos Flávios, mas que uma parte deles se manteve em funcionamento durante todo o período da Romanização (ALMEIDA, 2003, 272-285 e 395-406).

Neste momento, mercê da presença de cerâmica que cobre todas as cronologias associadas à Romanização, julgo que a Cividade de Bagunte se encaixa no modelo de uma ocupação contínua, embora com expansões e contrações urbanísticas significativas ao longo da sua existência, sendo esta a última fase da sua vida. Contudo, esta afirmação deve ser lida com cautela, pois os dados disponíveis para fazer uma afirmação tão concludente são ainda muito escassos e, em alguns casos, provenientes de contextos arqueológicos com registo pouco fiáveis.

Não faltam exemplos de povoados, com o Monte Mozinho, o Castro de São Lourenço e o Castro de Castelo de Neiva à cabeça, onde no século IV, se conhecem revitalizações da vida urbana, em muitos casos tornados prestadores de serviços daqueles que tinham optado por descer para a planície, quando os efeitos da romanização se começaram a fazer sentir na Gallaecia meridional.

Em termos urbanísticos, a Cividade de Bagunte apresenta um modelo claramente com influências da Romanização, baseado na ortogonalidade delineada por arruamentos, em bairros subdivididos em núcleos habitacionais, organizados em redor de pátios centrais e compostos por um misto de compartimentos redondos, quadrangulares/retangulares, com ângulos arredondados ou retos. Em suma, apresenta uma marca distintiva das alterações efetuadas por volta da segunda metade do século I, sob a influência da dinastia dos Flávios (ALMEIDA, 2015). As datações de $\mathrm{C}_{4} 4$ obtidas para estas estruturas parecem indiciar que o início destas alterações terá ocorrido um pouco mais cedo, logo após o câmbio da Era e ter-se-ão prolongado pela dinastia dos Flávios. Se assim é, então enquadram-se na fase III (A e B) proposta por Armando Coelho (SILVA, 1986, 66-67).

É comummente aceite pela historiografia da Cultura Castreja que o declínio da ocupação destas infraestruturas habitacionais começou com a integração do seu território na esfera político-administrativo-militar romana, que causou uma fragmentação das suas estruturas tradicionais. Esse movimento, embora possa ter iniciado antes, só se torna visível no século I, com a dinastia dos Flávios e acentuou-se no século II (ALMEIDA, 2003, 272-285).

As datações de C14 também permitiram perceber que nesta mesma área existem estratos arqueológicos que podem ser enquadrados numa cronologia um pouco mais antiga, mas que não recuam para além do II a.C., ou seja, enquadram-se na fase IIIA da periodização defendida por Armando Coelho (SILVA, 1986, 66-67).

Sobre a realidade imediatamente anterior à renovação empreendida entre o câmbio da Era e a dinastia dos Flávios, pouco ainda se sabe, em parte pela exiguidade da área escavada recentemente.

Esta exiguidade de dados é, no entanto, preenchida por uma inscrição revelada na intervenção de 2017. Esta foi descoberta no alicerce do muro de perímetro da unidade habitacional 3, com o campo epigrafado voltado para o arruamento, deposta em posição deitada e posicionada abaixo da cércea do pavimento. Portanto, não estava visível, indiciando uma deposição secundária. Na inscrição pode-se ler "VIRIVS FECIT". Se a inscrição comemorativa não está na sua deposição primária, deduz-se que "VIRIVS" mandou fazer algo distinto do edifício onde foi incorporado. Por outras palavras, terá de ser anterior às construções cuja datação medeia entre o câmbio da Era e o período dos Flávios, mas não pode ser anterior ao início da Romanização. A existir, essa ocupação corresponderá a um período intermédio da fase IIIA da periodização da Cultura Castreja proposta por Armando Coelho (SILVA, 1986, 66-67).

Quando a escavação ultrapassa as camadas relacionadas com o final do século II a.C., o que se encontra é uma realidade estratigráfica não antrópica. Essa camada será um solo vegetal anterior à ocupação humana daquela área. Esta realidade significa que, em todos os quadrados escavados no século XXI, sob a ocupação flaviana existem estratos datáveis do século II a.C., mas não se encontram dados mais antigos. Perante este quadro, pode-se pensar que as zonas escavadas no século XXI são área de expansão da Cividade de Bagunte, pois faltam as estruturas e os estratos arqueológicos que justifiquem a presença de espólio mais antigo, nomeadamente os fragmentos de tipo "Alpiarça" que se encontram no Museu de História Natural e da Ciência da Universidade do Porto. Estes foram encaixados numa faixa cronológica situadas entre os séculos VII e V a.C. (ALMEIDA, 2020) e que fazem pensar que o início da ocupação 
deste povoado possa ter acontecido durante a fase I da periodização proposta por Armando Coelho para a Cultura Castreja.

Mais recentemente, em 2018, recolheu-se uma fíbula em bronze do tipo Ponte 22a ou 22b. Esta terá uma cronologia que se situa entre o século VII a III a.C. (PONTE, 2004, Quadro 1b), corroborando a hipótese de estarmos numa área de expansão da Cividade de Bagunte.

Esse movimento ter-se-á iniciado no século no final do século II a.C. e prolongou-se até ao período dos Flávios.

Fica, no entanto, por responder onde se situa o núcleo mais ancestral da Cividade de Bagunte, o que justifica peças arqueológicas mais antigas. A resposta a esta questão talvez possa ser dada com o alargamento da área sondada, para outras áreas (Zona 2 e 3?) topograficamente mais elevadas e menos perturbadas por trabalhos arqueológicos anteriores.

Todas as áreas sondadas, desde o século XIX à atualidade, encontram-se no interior de, pelo menos, duas linhas de muralhas pétreas, aparentemente, concêntricas (há ainda um troço de muralha em terra, sobre a qual recaem mais dúvidas do que certezas, nomeadamente quanto à sua forma, dimensão e datação). Ainda não foi possível datar a construção das muralhas pétreas.

A muralha mais interior foi alvo de uma sondagem na atualidade, revelando que se encontrava muito destruída. Deu para perceber que era composta por duas faces opostas, distantes entre si em cerca de $1,4 \mathrm{~m}$, sendo que o espaço interior foi cheio com pedra não aparelhada e terra.

Esta muralha tem um pormenor interessante e que corresponde a uma caixa de escadas aberta na espessura do muro e que dava acesso ao topo da estrutura defensiva, pelo lado interior.

Durante as intervenções dos anos 40 do século XX, esta área deverá ter sido parcialmente escavada. Prova disso mesmo foi a recolha de uma conta de colar, de tom azul escuro, que depois de analisada, quanto à sua composição química, provou-se ser feita com vidro da Boémia. Por outras palavras, não poderia ser anterior ao século XIX e terá sido perdida por alguma das muitas trabalhadoras contratadas por Russel Cortez. Foi encontrado numa das unidades estratigráfica que, em algumas áreas, cobria o terreno geológico, sendo evidentes as reservas que pendem sobre os dados recolhidos nestas sondagens. Para procurar uma resposta para a datação das mu- ralhas da Cividade de Bagunte, num futuro próximo será aberta uma vala de sondagem que pretende, também do ponto de vista estratigráfico, determinar uma relação entre as estruturas habitacionais da acrópole e a primeira linha de muralha pétrea. Talvez nessa altura seja possível avançar com dados mais seguros.

Uma nota para futuras investigações prende-se com o acumular de um conjunto significativo de elementos que, devidamente trabalhados por outras ciências, poderão dar um quadro mais vasto e rico sobre a evolução da Cividade de Bagunte ao longo da sua "vida". Alguns destes trabalhos têm, potencialmente, a capacidade de criar sinergias interessantes. Neste rol incluem-se os trabalhos de antropologia física, de antracologia e carpologia e de cromatogramas.

Já foram ensaiados alguns esforços nesse sentido, mais numa perspetiva de comprovar que os dados estavam disponíveis, mas também para afinar estratégias futuras que permitam maximizar as recolhas de informação, algo que será aplicado em escavações futuras.

Assim sendo e apesar dos dados tratados não serem estatisticamente relevantes e de possuírem diversos problemas na sua recolha (entre outros, os dados resultam de recolhas não sistemáticas e de seleção aleatória), sabe-se que na Cividade de Bagunte estão presentes diversas espécies vegetais, onde predominam os "Quercus" de folha caducifólia, mas também das famílias das "Leguminosae", nomeadamente o "Cytisus scoparius" (giesteira das vassouras) e o "Ulex" (tojo). A amostra tratada possui, em número consideravelmente menor, um conjunto de espécies que usualmente são associadas a galerias ripícolas, como o "Salix" (salgueiro), o "Corylus avellana” (aveleira), a "Alnus” (amieiro) e a "Frangula sp.” (frângula). Uma outra espécie detetada foi a "Prumus Avium/Cerasus" (cerejeira brava/ginja) que, por norma, se posiciona nos limites de campos agrícolas. Também foram identificados carvões de "Erica" arbórea (Urze-branca) que etnograficamente está associada a atividades com necessidades caloríficas elevadas. Residualmente, aparecem carvões de "Quercus" de folha perenifólia, de "Rhamnus sp” (espinheiro) e de "Vitis Vinifera” (videira). Normalmente associados a contexto da antiguidade tardia, a "Castanea Sativa" (castanheiro) também marcou presença ${ }^{4}$.

4. A identificação destes elementos ficou a cargo de Catarina de Oliveira Magalhães, estudante de mestrado em Arqueociências, a quem agradeço a colaboração. 
Também estão a ser feitos estudos sobre os elementos carpológicos, mas os mesmos encontram-se numa fase mais atrasada, pelo que não é possível apresentar qualquer dado neste momento.

Numa abordagem complementar, foram realizados diversos estudos sobre os resíduos químicos absorvidos pela cerâmica, através da cromatografia. Uma vez mais, estes primeiros testes serviram para comprovar a existência de dados e afinar métodos de recolha, de manuseamento e armazenamento das peças a testar.

Os primeiros testes mostram que a cerâmica possui elementos químicos compatíveis com a sua utilização. Num dos casos, um dolium, foi possível determinar que o mesmo foi revestido interiormente por cera de abelha. Existem outros exemplos, nomeadamente ânforas, que atestam o uso de resina de pinheiros e ciprestes. Na cerâmica comum aparecem vestígios de óleos vegetais, com elevado grau de probabilidade de serem de azeite e gorduras animais. De entre os diversos problemas levantados por esta investigação, o que mais chamou à atenção é a falta de marcadores resultantes da queima de alimentos ${ }^{5}$. Também numa fase inicial está o estudo de material osteológico, provavelmente pertencente a fauna consumida, mas cujos ossos aparentar terem sido expostos a altas temperaturas. Este material foi encontrado numa entulheira, misturados com material diverso, que incluída escória metálica e vítrea, bem como uma grande quantidade de cinza.

Quando nos for possível a visão cruzada destes três trabalhos-haverá um conhecimento mais abrangente sobre o modo de vida neste povoado, devidamente enquadrado cronologicamente.

5. Estes testes, o tratamento da informação e a sua interpretação foram realizados por César Oliveira, Doutorado em Química pela Universidade do Porto e Post-Doc pela Universidade de Aveiro, a quem agradeço a colaboração.

\section{BIBLIOGRAFIA}

ALMEIDA, Carlos A. Ferreira de (1974) - Cerâmica Castreja, in Revista de Guimarães, Vol. LXXXIV (1-4), Guimarães, 1974.

ALMEIDA, Carlos Alberto Brochado de (1995) - A romanização no concelho de Vila do Conde, Guimarães.

ALMEIDA, Carlos A. Brochado de; ALMEIDA, Pedro Miguel D. Brochado de (2015) - Alguns Apontamentos sobre a Cividade de Bagunte - Vila do Conde, in Portugália, Nova Série, Vol. 36, Porto, DCTP-FLUP, pág. 49-62.

ALMEIDA, Carlos A. Brochado de; MORAIS, Rui, ALMEIDA, Pedro Brochado de, FILIPE, Ana Rita (202O) - Materiais arqueológicos da Cividade de Bagunte presentes no Museu de História Natural e da Ciência da Universidade do Porto (prelo a publicar na Revista Portugália).

ARGOTE, Jerónimo Contador de (1744) - Memórias para a História Eclesiástica do Arcebispado de Braga, tomo III, Braga.

CALO LOURIDO, Francisco (1994) - A Plástica da Cultura Castrexa Galego-Portuguesa, Vol. I, Museo de Pontevedra, Pontevedra.

CORTEZ, F. Russel (1948) - Actividade Arqueológica em Portugal durante 1947, in Archivo Español de Arqueologia, Vol. XXI (72), Madrid, 269-281.

COSTA, A. Carvalho da (1868-1869) - Corografia Portugueza e Descripçam Topografica do Reino de Portugal, Lisboa, 3. Vol, 2 $2^{\underline{a}}$ Edição, Braga,

DINIS, António Pereira (1993) - Ordenamento do Território do Baixo Ave no I Milénio a.C., Dissertação de Mestrado, Policopiado, FLUP, Porto.

KALB, Philine (1980) - Zur Atlantischen Bronzezeit in Portugal, Germania.

PINTO, Paulo Costa (1997) - Raízes de Vila do Conde, edição APPA-VC, Vila do Conde.

PINTO, Paulo Costa (1998) - Arqueologia e Administração Local, Actas dos Encontros O Archeólogo português. 100 anos de Arqueologia, edição APPA-VC, Vila do Conde.

PINTO, Paulo Costa (2003) - O Parque Arqueológico da Cividade de Bagunte. Projeto de Dinamização Cultural da área da Cividade de Bagunte, in Atas Encontros do Património de Vila do Conde, edição Câmara Municipal de Vila do Conde, 125-159.

PONTE, Salete da (2004) - Retrospetiva sobre Fíbulas proto-históricas e romanas de Portugal, in Revista Conimbriga, Volume XLIII, Faculdade de Letras da Universidade de Coimbra, Coimbra.

QUEIROGA, Francisco (1996) - As Sociedades do 1º Milénio a.C. do vale do Ave e as metalurgias do Bronze e Ferro, $I^{\circ}$ Colóquio "Mineração e Metalurgia do Ferro (da antiguidade aos nossos dias), Torre de Moncorvo. 
ROMERO MASIÁ, Ana (1976) - El Habitat Castreño. Asentamientos y Arquitectura de los Castros del N. O. Peninsular, Santiago de Compostela.

SARMENTO, Martins (1999) - Apontamentos de Arqueologia. Antiqua, edição Sociedade Martins Sarmento, Guimarães.

SEVERO, Ricardo, CARDOZO, Artur (1886) - Notícias archeologicas sobre o Monte da Cividade, Revista de Guimarães, III, Guimarães.
SILVA, Armando Coelho Ferreira da (1986) - A Cultura Castreja no Noroeste de Portugal, EDIÇÃO Câmara Municipal de Paços de Ferreira, Paços de Ferreira.

TEIXEIRA, C.; MEDEIROS, A. C. (1965) - Noticia explicativa da folha 9-A (Póvoa de Varzim) da Carta Geológica de Portugal à escala 1:50 ooo, Direcção Geral de Minas e Serviços Geológicos, Serviços Geológicos de Portugal, Lisboa.

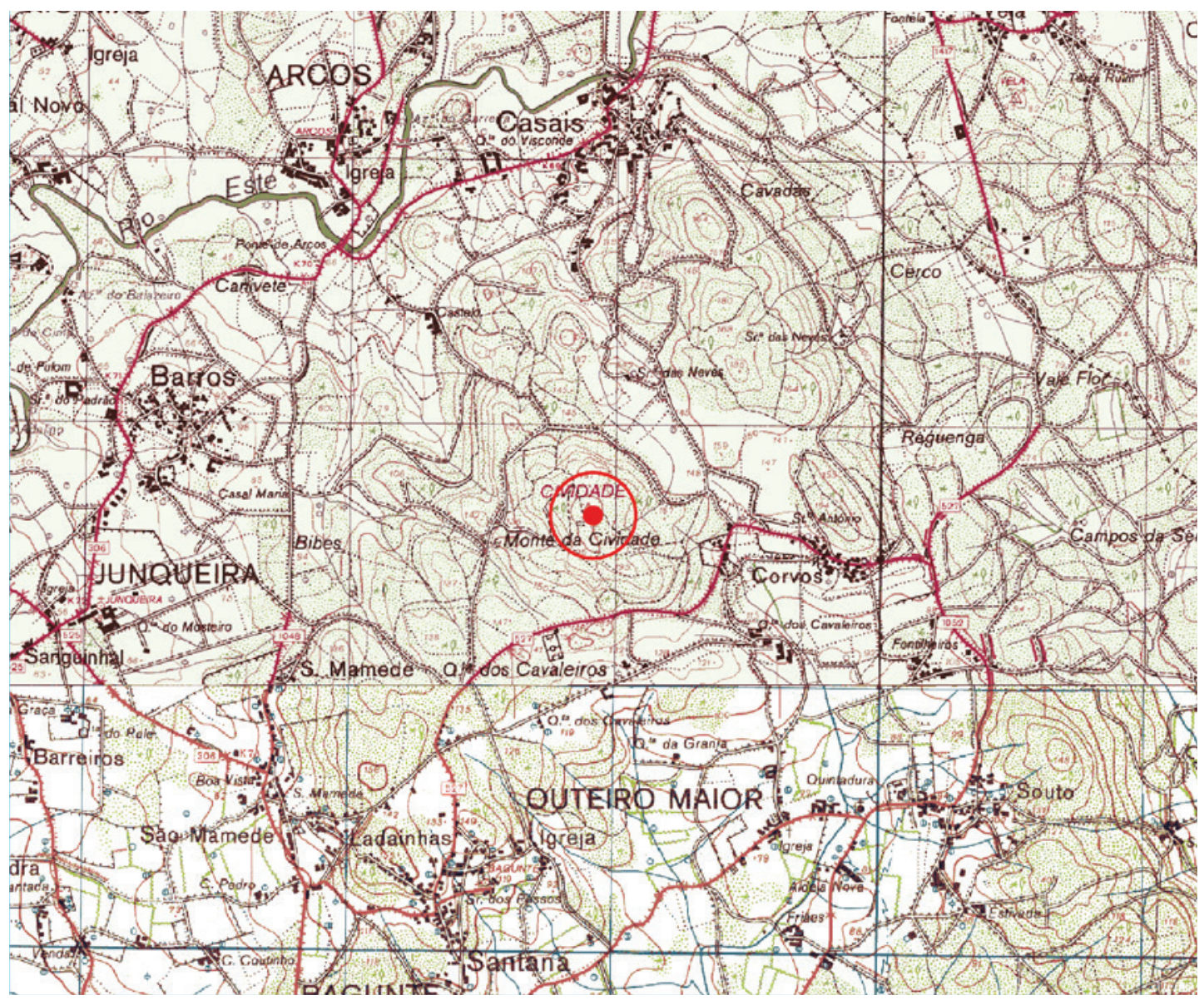

Figura 1 - Localização. 


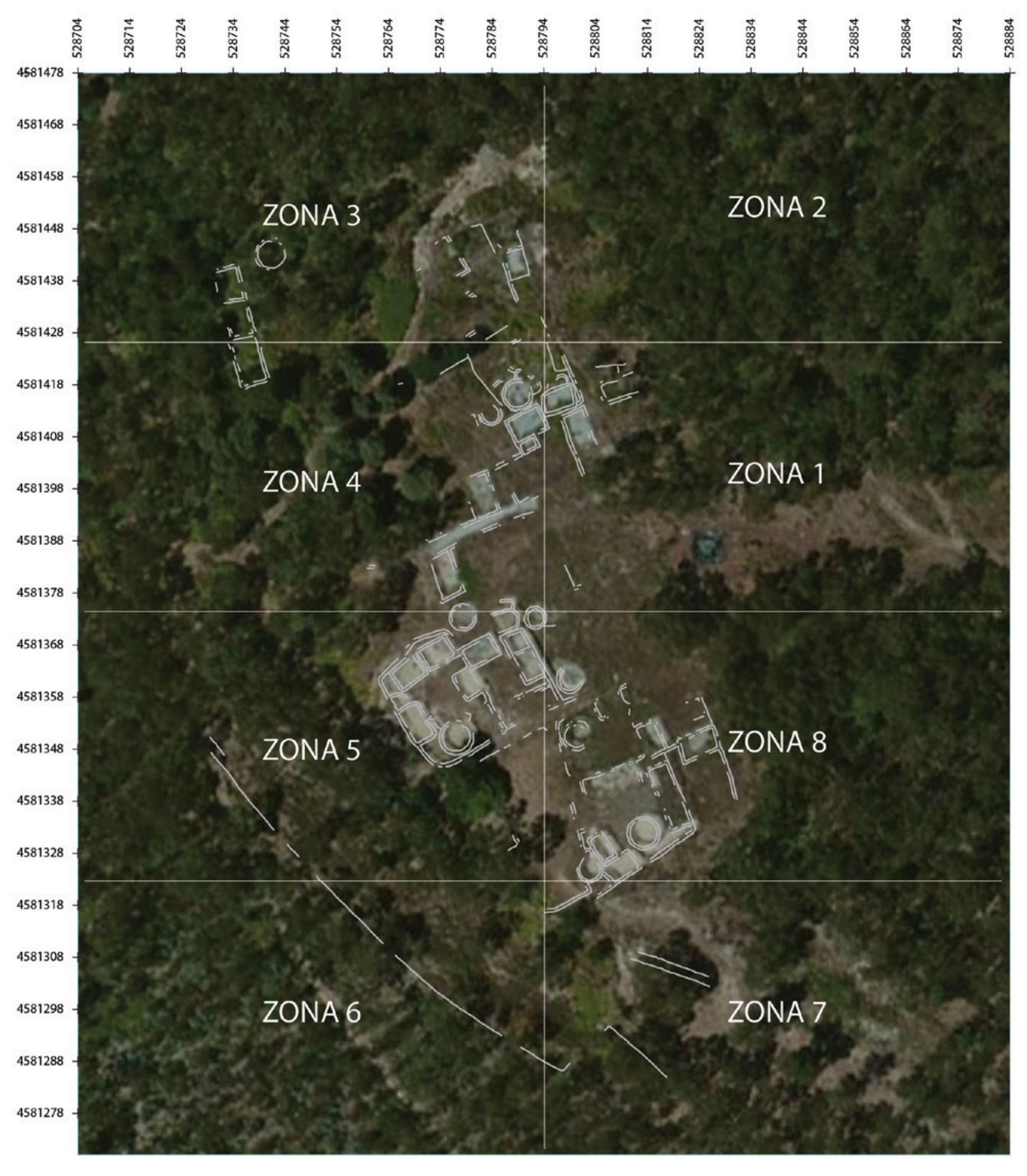

Figura 2 - Divisão da Cividade de Bagunte em zonas. 


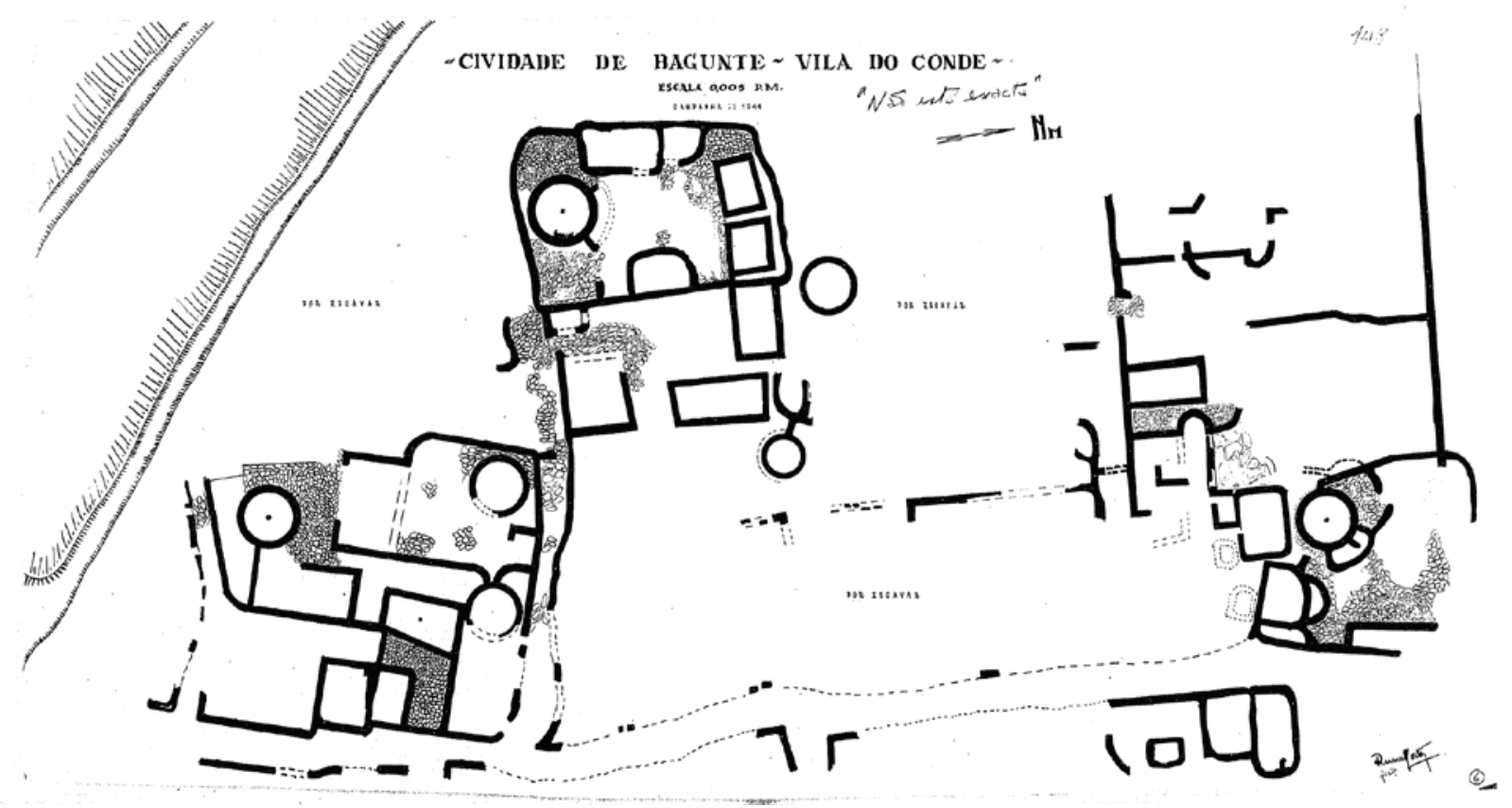

Figura 3 - Planta da Cividade de Bagunte feita por Russel Cortez (arquivo DGEMN).

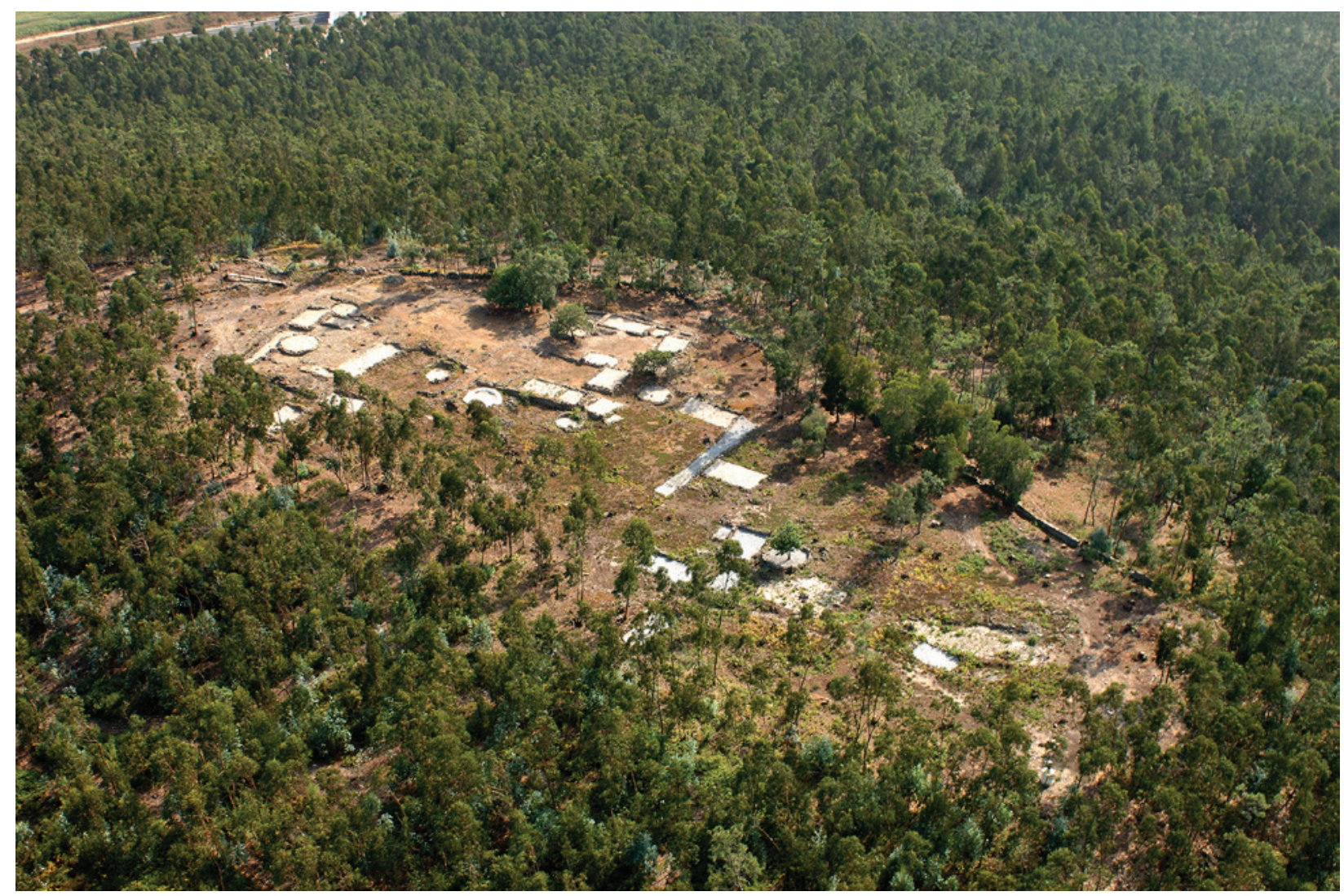

Figura 4 - Imagem aérea da acrópole da Cividade de Bagunte. 


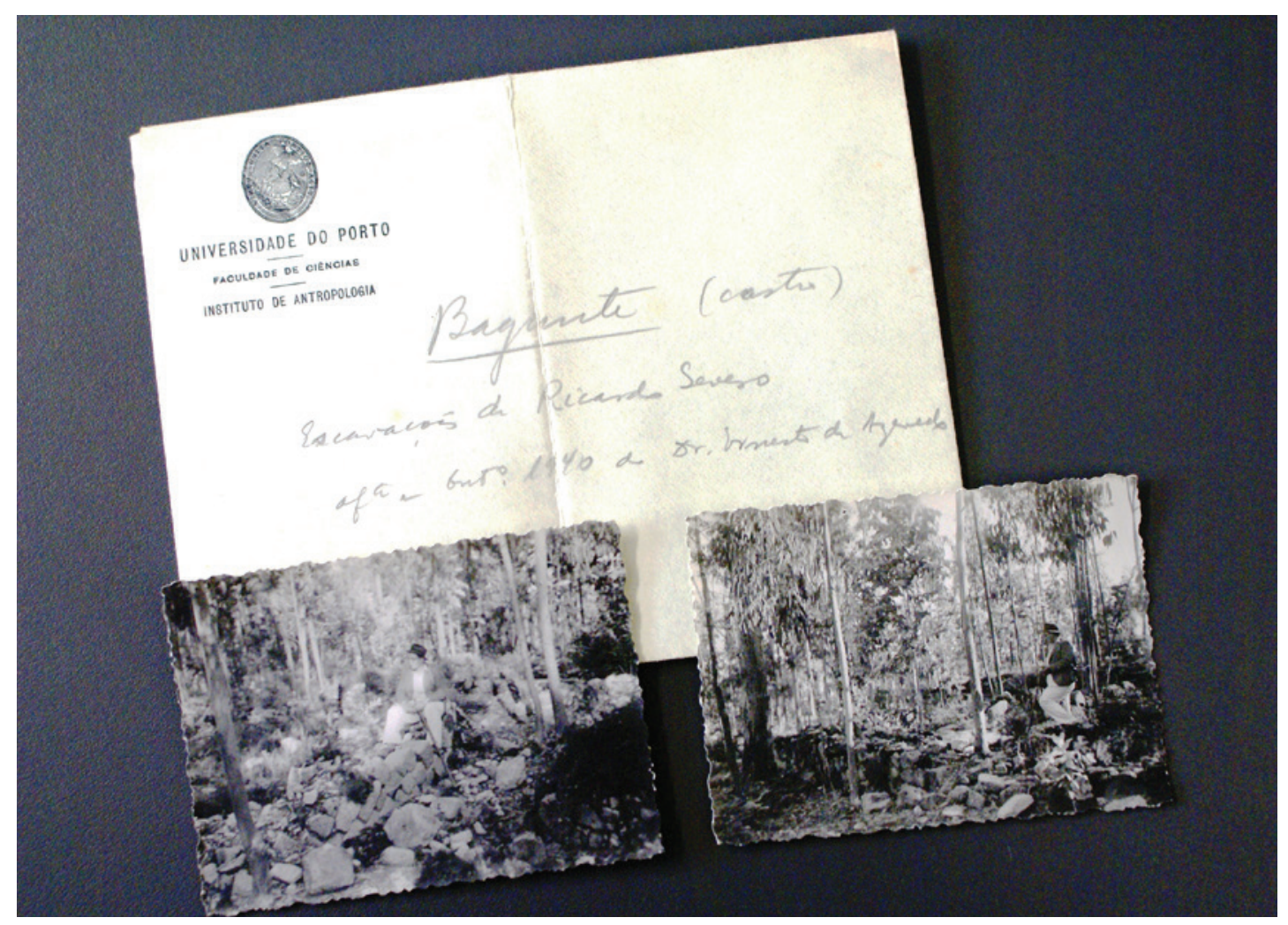

Figura 5 - Imagens da escavação de Ricardo Severo (Arquivo Museu de História Natural e da Ciência da Universidade do Porto).

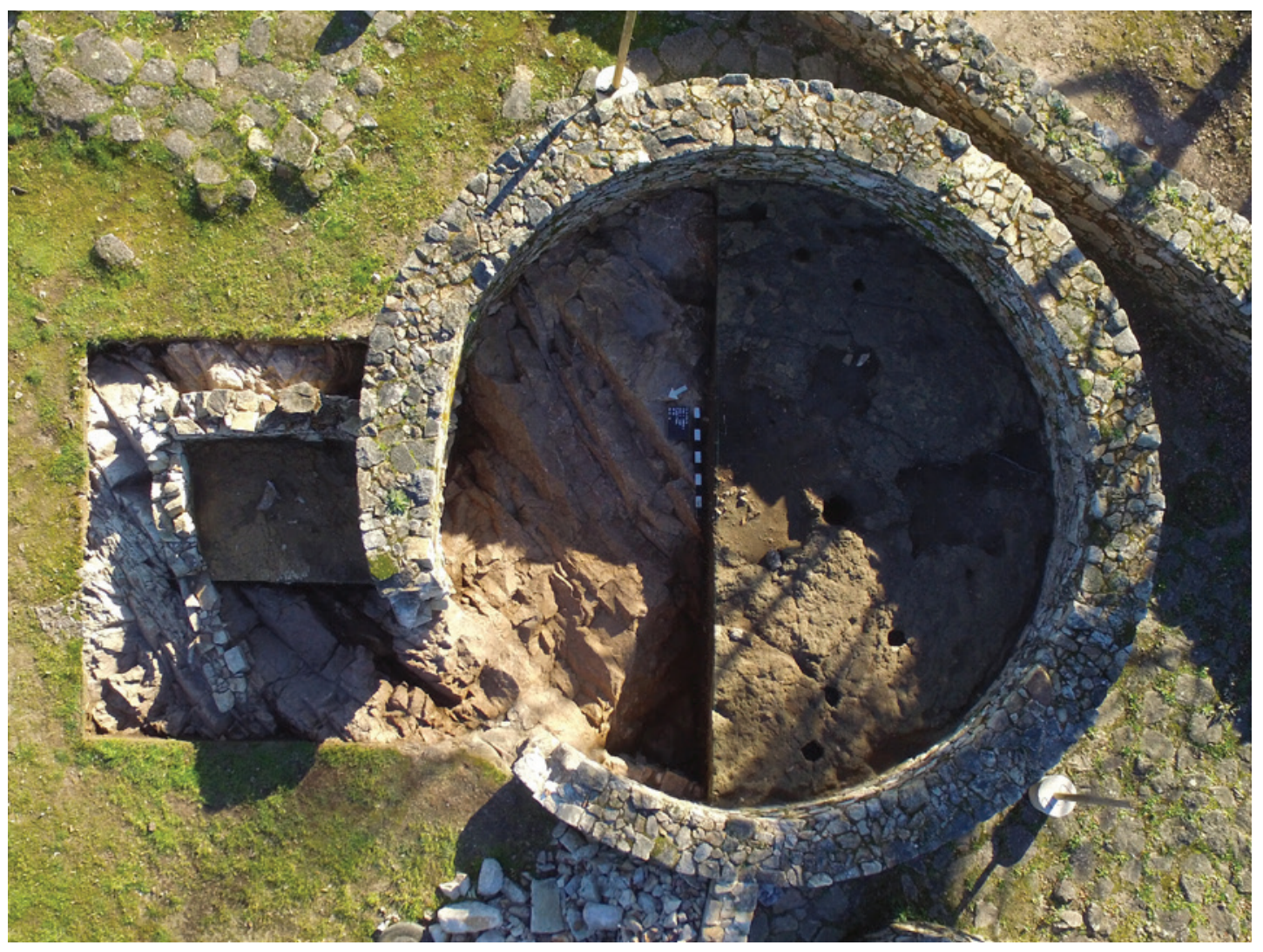

Figura 6 - Imagem escavação efetuada na zona 5. 


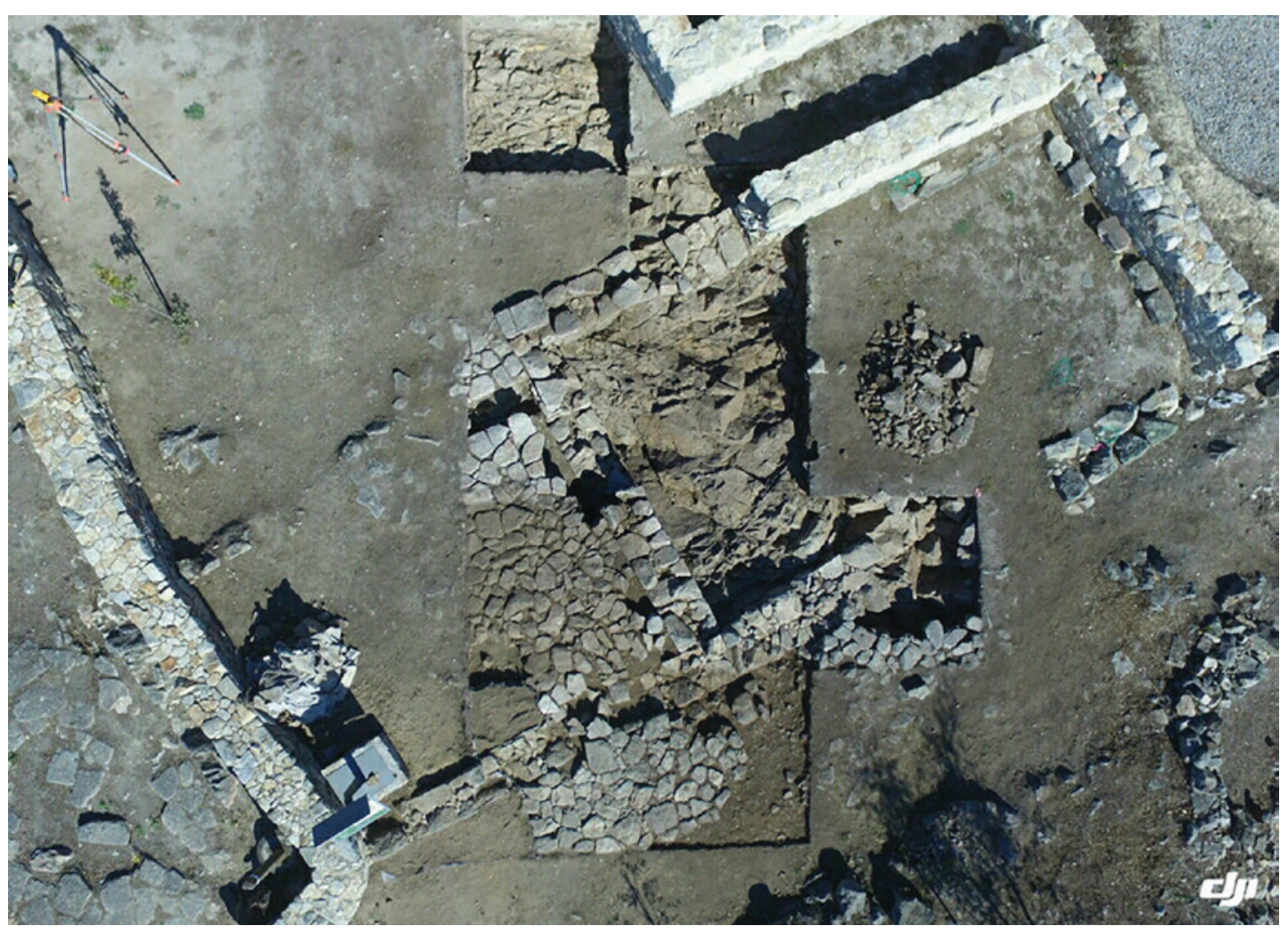

Figura 7- Imagem escavação efetuada nas zonas 5 e 8.

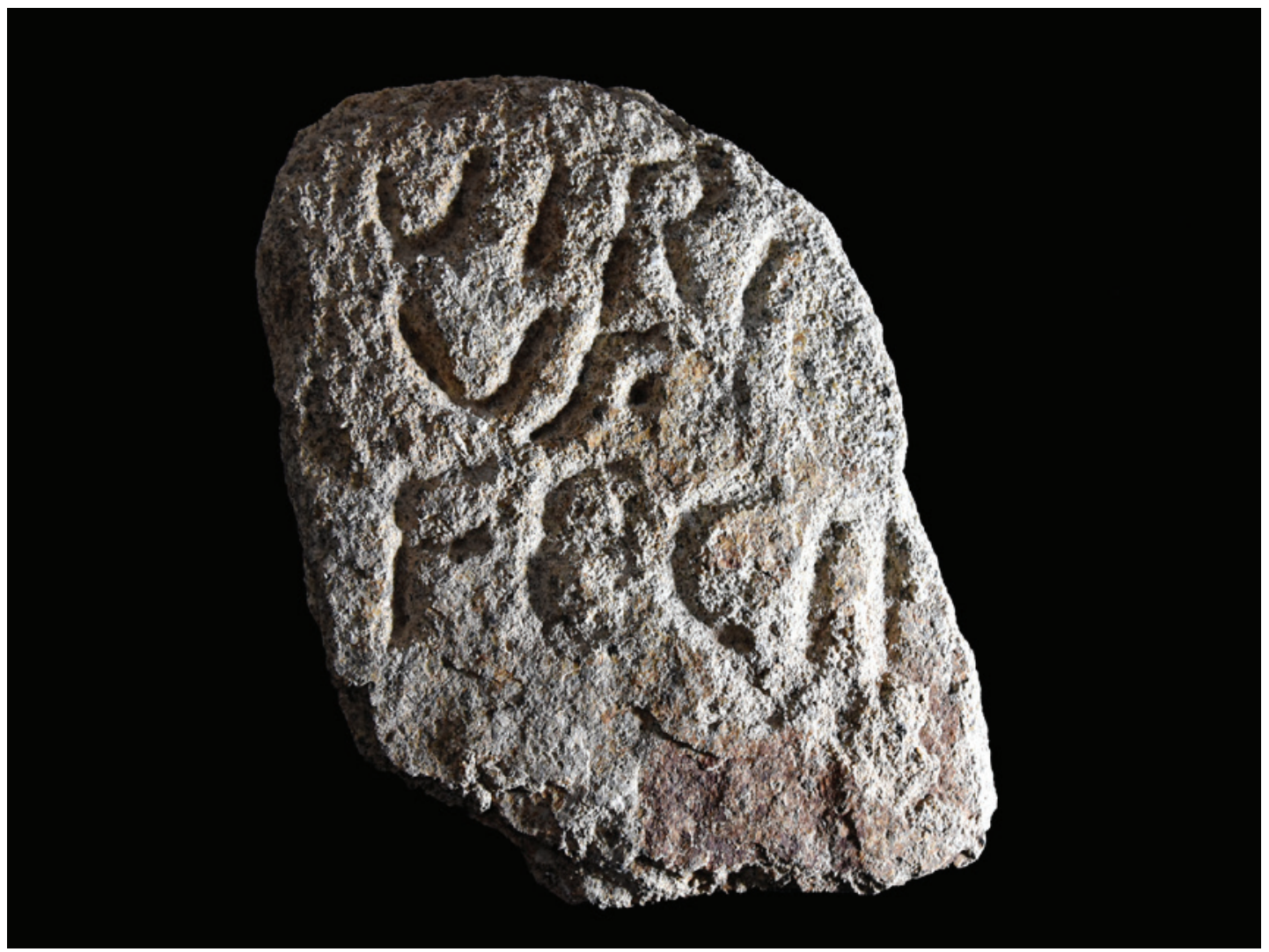

Figura 8 - Imagem escavação efetuada nas zonas 5 e 8. 


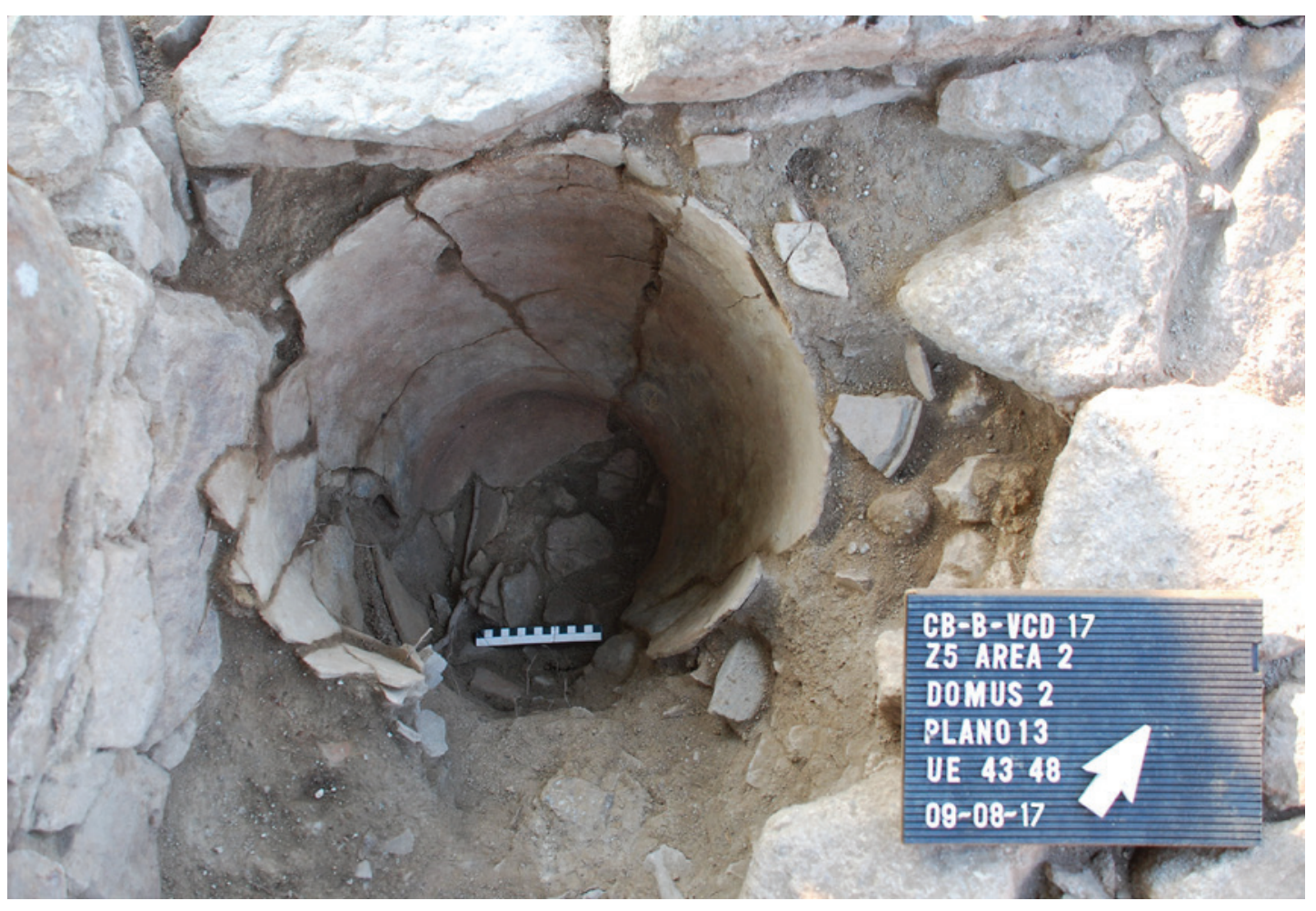

Figura 9 - Imagem de dolium encontrado na zona 5. 



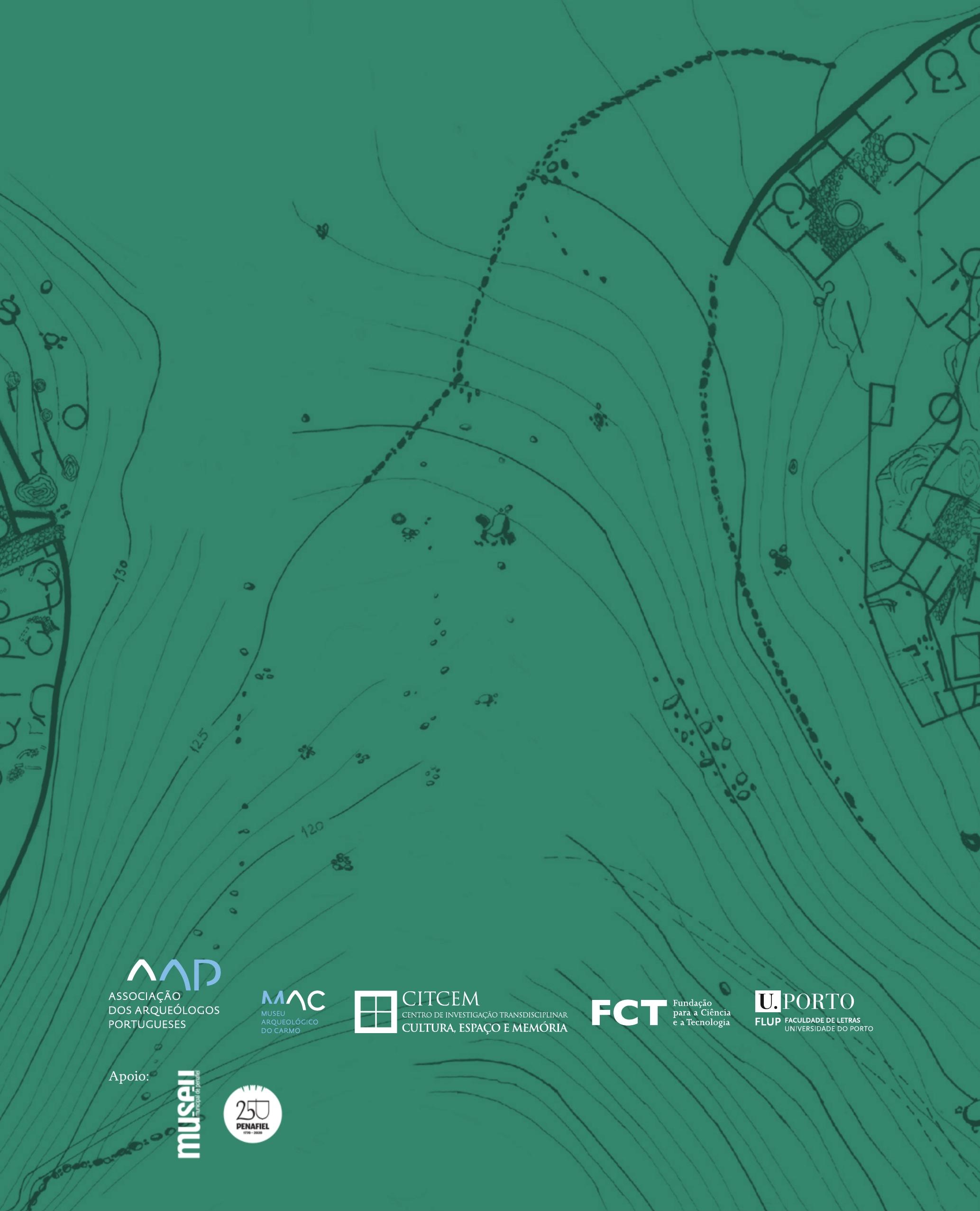

